\title{
Improving Client-Oriented Approach in the Provision of Public Services in the Context of Digitalization
}

\author{
Anna Zvereva \\ The Russian Presidential Academy of \\ National Economy and Public \\ Administration \\ Moscow, Russia \\ sw_an@mail.ru
}

\author{
Svetlana Ilyashenko \\ Department of trade policy \\ Plekhanov Russian University of \\ Economics \\ Moscow, Russia \\ ilyashenko.sb@rea.ru
}

\author{
Ekaterina Golubtsova \\ Plekhanov Russian University of \\ Economics \\ Moscow, Russia \\ katarina.golubtsova@gmail.com
}

\begin{abstract}
The Quality of public services is a very significant and urgent problem of modern reality.

Training of employees of Executive authorities in modern conditions is a socially important issue due to the fact that the client-oriented approach is extremely important. At the same time, the set of organizations providing state and municipal services plays an important role in the organization of relations with the population of the population, indirectly affects the maintenance of social stability in the state.

Implementation of the client-oriented approach is impossible without proper training of employees of the relevant authorities. And for the full implementation of the client-oriented approach it is extremely important to monitor the quality of public and municipal services.

Taking into account these components for the purpose of qualitative implementation of the mechanism of clientorientation in the provision of public services in this study, the main theoretical issues characteristic of modern reality are considered. They are largely due to the digitalization of public relations in General, the introduction of e-government. The study also offers a number of practical solutions for the qualitative implementation of the client-oriented approach.
\end{abstract}

Keywords: citizen-government interaction, public service, egovernment, digitalization

\section{INTRODUCTION}

E-government holds enormous potential for improving the administrative efficiency of public institutions, encouraging democratic governance, and building trust between citizens/private sector and governments [1].

In foreign practice, digital transformation in public administration is not limited to changes in the provision of public services. The possibilities of modern "breakthrough" digital technologies (first of all, "big data", Internet of things, artificial intelligence, distributed registry) for the transformation of public policy and rulemaking, revenue administration, state property management, control and Supervisory activities are significant. At the same time, digital technologies are used for the purposes of planning, monitoring and evaluating the performance of authorities. The effect of digitalization is estimated by the impact of technologies on these results [2].

Businesses, far more frequently than citizens, need government information and services to exert their rights and duties. In optimizing their service delivery processes, governments tend to focus on a set of communication channels they offer to businesses to deliver these services. However, in reality, businesses use not only a plethora of different channels but also multiple information sources, extending beyond governments [3].

Many developing countries are now experiencing revolution in e-government to deliver fluent and simple services for their citizens. However, governmental sectors face many challenges in using its e-governments' services and its infrastructure, improving current services or developing new services; as data and applications increasingly inflating, IT budget costs, software licensing and support and difficulties in migration, integration and management for software and hardware. These challenges may lead to failure of e-governments' projects [4].

The principles of providing state and municipal services in the territory of the Russian Federation are formulated in the Federal law of July 27, 2009 No. 210-FZ "On the organization of providing state and municipal services" and include the need to comply with a number of fundamental rules, which include:

- legality of the provision of state and municipal services by the relevant authorities;

- $\quad$ procedure for applying for the provision of state and municipal services;

- the lawfulness of collecting from applicants the state fee for the provision of state and municipal services;

- openness of activities of bodies providing public services;

- availability of applying for the provision of public and municipal services;

- the possibility of obtaining state and municipal services in electronic form, if it is not prohibited by law.

Different in nature and volume of consumer requests of state and municipal services predetermine the requirements for their provision.

Legislative acts in force on the territory of the Russian Federation, affect various aspects of the mechanism of public services, especially their implementation in the territory of the Russian Federation. Despite the significant reflection of this problem, at present the issues of forming a clientoriented approach to the provision of state and municipal services remain relevant and require further research and development. 
As part of the reform of the mechanism for providing public services, the possibility of their provision in electronic form is envisaged. This method is an optimized version of the implementation of its functions by Executive authorities in the territory of the Russian Federation. In addition, it reduces the costs of the consumer of public services (applicant), since the appeal of applicants and their contact with public authorities can be implemented through multifunctional centers for the provision of state and municipal services. The provision of a complex of interrelated public services by Federal Executive authorities, Executive authorities of the subjects of the Russian Federation and local authorities on the principle of "single window" became possible thanks to interdepartmental interaction without the participation of the applicant.

In the course of the study, the analysis of modern mechanisms for the implementation of public services provided by the Executive authorities of the Russian Federation was carried out.

In accordance with the norms of the current legislation, the basic concepts and definitions are introduced. Here are the most important of them, which embody the essence of public services:

1) the state service (SS) provided by Federal Executive body, body of the state off-budget Fund, Executive body of the state power of the subject of the Russian Federation, and also local government body at implementation of the separate state powers transferred by Federal laws and laws of subjects of the Russian Federation (further-the state service), - activity on implementation of functions respectively of Federal Executive authority, the state off-budget Fund, Executive body of the state power of the subject of the Russian Federation, and also local government body at implementation of the separate state powers transferred by Federal laws and laws of subjects of the Russian Federation (further - bodies providing the state services) which is carried out at requests of applicants within the powers of bodies providing the state services established by regulatory legal acts of the Russian Federation and regulatory legal acts of subjects of the Russian Federation;

2) municipal service (MS) provided by the local selfgovernment body (hereinafter-municipal service) - activities for the implementation of the functions of the local selfgovernment body (hereinafter - body providing municipal services), which is carried out at the request of applicants within the powers of the body providing municipal services, to address issues of local importance, established in accordance with the Federal law of October 6, 2003 N 131 "on General principles of organization of local selfgovernment in the Russian Federation" and the statutes of municipalities, as well as within the specified Federal law of the rights of local self-government to address issues not related to issues of local importance, the rights of local governments to participate in the implementation of other state powers (not transferred to them in accordance with article 19 of the specified Federal law), if this participation is provided by Federal laws, rights of local governments on the decision of other questions, not referred to the competence of local governments of other municipalities, public authorities and not excluded of their competence Federal laws and laws of subjects of the Russian Federation, in case of adoption of municipal legal acts on realization of such rights;
3) the applicant is a natural or legal person (except for state bodies and their territorial bodies, bodies of state extrabudgetary funds and their territorial bodies, bodies of local self-government) or their authorized representatives who applied to the body providing state services with a request for the provision of state or municipal services, expressed orally, in writing or electronically.

\section{LiterATURE REVIEW AND RESEARCH METHODS}

In the course of the research a number of methods were used, including such General scientific ones as: observation, analysis and synthesis, induction and deduction, comparison and description, qualitative and quantitative analysis, system approach, unity of historical and logical approaches. Among the private and scientific applied: graphic, statistical, mathematical methods of data processing, modeling, and expert.

These methods made it possible to identify modern critical indicators that determine the effectiveness of public services, to present the author's interpretation of the results. Comparative analysis allowed us to separate the object of study in terms of the main elements shaping the process of provision of public services and their Association to present a set of compositional elements, identify features of the mechanism of provision of public services and achieve goals and objectives of the study.

These methods made it possible to identify modern critical indicators that determine the effectiveness of public services, to present the author's interpretation of the results. Comparative analysis allowed us to separate the object of study in terms of the main elements shaping the process of provision of public services and their Association to present a set of compositional elements, identify features of the mechanism of provision of public services and achieve goals and objectives of the study.

Changing governance paradigms has been shaping and reshaping the landscape of citizen-administration relationships, from impartial application of rules and regulations by administration to exercise its authority over citizens (bureaucratic paradigm), through provision of public services by administration to fulfil the needs of citizens (consumerist paradigm), to responsibility-sharing between administration and citizens for policy and service processes (participatory paradigm) [5].

It is necessary to consider that with the imperative of egovernment for better transparency, accountability and public services, the problem of low-level citizen adoption of e-government services has been recognized in developed and developing countries [3].

\section{RESULTS}

With the global evolution of information and communication technology (ICT), organizations need to keep up-to-date with the trends. Whilst most countries are able to respond to these technological changes by drawing on the resources available to them, organizations tend to find it more difficult to keep up [7].

E-government presently has evolved into two identifiable stages. The first stage is the information dissemination phase in which governments catalogue information for public use. The second phase is transaction-based e-government in 
which there is e-service delivery such as paying taxes online [8].

In determining the main elements of the mechanism of providing public services for the participants of relations, in developing methodological approaches to the formation of a model of communicative and customer-oriented behavior of employees of Executive authorities on the basis of the use of modern digital tools of professional activity taking into account the interests of consumers of public services. The implementation of the mechanism for providing public services is based on compliance with the main characteristics and set of mandatory principles in their provision, taking into account the requirements of the current legislation.

To measure the quality of e-services, the authors suggest using the following criteria: quality of information, technical efficiency, privacy and communication with the employee [6].

The essential features inherent in SS and MS are presented in figure 1. The first of these criteria implies-the definition of categories of individuals and (or) legal entities that are consumers of services, that is, the specification of the applicant (consumer).

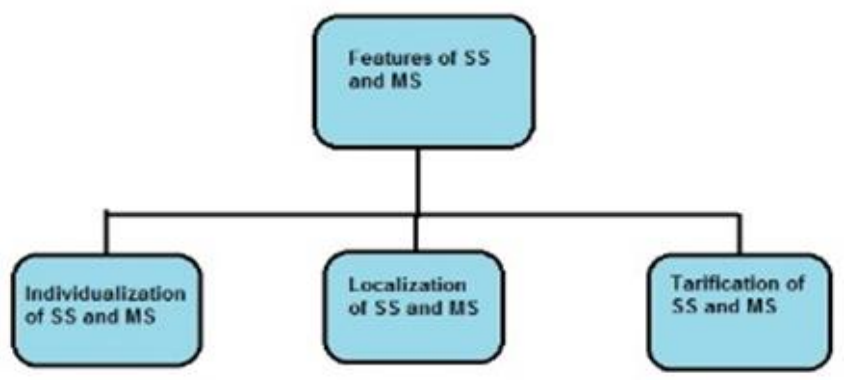

Fig. 1. Characteristics of the rendering state and municipal services

The following criterion is directly linked to the SS, the need for treatment in connection with the implementation of the rights and duties of citizen as user of public services to the relevant body and the provision of SS or MS directly by a public authority with appropriate powers. Finally, the third criterion involves the need to establish marginal prices (tariffs) for the payment of relevant services by individuals or legal entities. Quite an important task in connection with the above criteria is to consider the possibility of implementing individual SS and MS commercial or nonprofit organizations, their associations. These criteria embody both economic and organizational characteristics of state and municipal services. It is necessary to take into account the observance of the principles of uniformity in accordance with the listed criteria, since non-compliance with the specified requirements entails socio-economic consequences. This is due to the fact that the applicant often refers to the state Executive authority in connection with the need to identify their legal rights or protect interests.

At the same time, maintaining the required level of quality of provision to citizens and organizations of SS and MS is dual. On the one hand, effective use of budgetary resources is required to create and maintain the mechanism of public services in accordance with modern requirements. On the other hand, a person applies for the necessary information or public services and thus wants to minimize their time costs, reduce red tape, and have a clear understanding of the procedure for the provision of public services. Difficulties quite often arise due to the fact that a number of services provide for the need for interdepartmental cooperation. Applying to several agencies at the same time is quite time-consuming due to possible difficulties in the interaction between the relevant departmental information systems.

\section{DISCUSSION}

Rapid developments in communication and information technologies in the world force local administrators to be more effective. For a local administrator to be elected again, satisfaction of citizens with the duties that need to be performed and the services provided is significant [10].

Increasing the availability of public and municipal services through the use of digital technologies is an important trend of our time. Differences are being smoothed, and opportunities for public and municipal services are becoming wider.

The use of information and communication technologies to support the activities of public authorities, allows realizing qualitatively new level of applicants state and municipal services, information on the results of activities of state bodies, which is to ensure the implementation of the functions of the electronic government of the Russian Federation.

Analysis of the current situation shows that it is necessary to comply with a number of conditions for the full implementation of the functions of e-government. These include: the need to equip Executive authorities with modern digital equipment in conjunction with the formation of information technology and communication infrastructure to ensure their activities, the development of technical solutions for the organization of a secure system of interdepartmental electronic document management, regulation of functions and processes of state and administrative management, their reorganization and optimization.

\section{CONCLUSION}

With the evolution of mobile technologies and its applications, more and more government agencies are putting forth a huge effort to encourage citizens to use mobile government services. Hence, the citizens' opinion is important to enhance the services and improve their engagement in the government services [9].

Access to public services is an important determinant of economic opportunities and well-being. [11]. Digital communication between government and citizens is pivotal to e-government [12].

Methodological developments, results of analytical procedures and practical recommendations obtained in the process of research can be used as a basis for modeling communicative competence and customer-oriented behavior of employees of Executive authorities. This provision, in turn, is a platform for improving the quality of relations between Executive authorities and recipients of public services.

A number of studies have shown that coupling of strategic directions of innovation development of retail with basic competition strategies enables retail technological systems to plan introduction of organizational, marketing, 
International Journal of Information Management, vol. 39, 2018, pp. 20-29.

informational, technological innovations approaching target competitive advantages [13].

Driven by the growing importance of the digital provision of government services (e-government), recent research has sought to develop and test conceptual models of citizen satisfaction and trust with these services [14].

The implementation of the results of this study will provide the most effective mechanism for the provision of public services. The application of the practical results of the study will allow to assess the individual component aspects that determine the level of customer satisfaction in the processes of obtaining public services and to develop on their basis recommendations to improve the quality of public services processes implemented by Executive authorities in the Russian Federation.

The authors share the view that with the imperative of egovernment for better transparency, accountability and public services, the problem of low-level citizen adoption of e-government services has been recognized in developed and developing countries [3].

Research by a number of scientists has shown that there is a lack of advanced technological solutions that can stimulate cooperation between the government and citizens [15].

We will list further transformation of separate aspects of activity on rendering of SS and MS in the context of use of the concept of the electronic government.

First, the procedure of preparation of the initial set of documents by the applicant is simplified, since implementing interdepartmental cooperation authorized employees have the opportunity to form this package, initiating the relevant requests.

Secondly, time is optimized, due to the fact that information about the progress of obtaining SS and MS is available to the user online around the clock.

Third, the process of obtaining SS and MS is optimized by concentrating the applicant's appeals in a single center for processing citizens ' applications.

Fourth, document flow is optimized through the use of electronic digital signature and electronic approval of documents.

\section{REFERENCES}

[1] Silas Formunyuy Verkijika and Lizette De Wet, "A usability assessment of e-government websites in Sub-Saharan Africa,"
[2] Digital future of public administration by results [Electronic source]. Available at: http://d-russia.ru/tsifrovoe-budushheegosudarstvennogo-upravleniya-po-rezultatam.html.

[3] Omar Al-Hujran, Mutaz M. Al-Debei, Akemi Chatfield, and Mahmoud Migdadi, "The imperative of influencing citizen attitude toward e-government adoption and use," Computers in Human Behavior, vol. 53, 2015, pp. 189-203.

[4] Kh. E. Ali, Sh. A. Mazen, and E. E. Hassanein, "A proposed hybrid model for adopting cloud computing in e-government," Future Computing and Informatics Journal, vol. 3, iss. 2, 2018, pp. 286-295.

[5] Tomasz Janowski, Elsa Estevez, and Rehema Baguma, "Platform governance for sustainable development: Reshaping citizenadministration relationships in the digital age," Government Information Quarterly, vol. 35, iss. 4, Supplement, 2018, pp. S1-S16.

[6] M. Soledad Janita, and F. Javier Miranda, "Quality in e-Government services: A proposal of dimensions from the perspective of public sector employees," Telematics and Informatics, vol. 35, iss. 2, 2018, pp. 457-469.

[7] O. R. Ashaye and Z. Irani, "The role of stakeholders in the effective use of e-government resources in public services," International Journal of Information Management, vol. 49, 2019, pp. 253-270.

[8] Christopher G. Reddick, "Citizen interaction with e-government: From the streets to servers?," Government Information Quarterly, vol. 22 , iss. 1,2005 , pp. $38-57$.

[9] I. Almarashdeh and M. K. Alsmadi, "How to make them use it?," Citizens acceptance of M-government, Applied Computing and Informatics, vol. 13, iss. 2, 2017, pp. 194-199.

[10] B. Bostanc1 and N. Erdem, "Investigating the satisfaction of citizens in municipality services using fuzzy modeling," Socio-Economic Planning Sciences, 2019.

[11] A. Fredriksson, "Location-allocation of public services - Citizen access, transparency and measurement. A method and evidence from Brazil and Sweden," Socio-Economic Planning Sciences, vol. 59, 2017, pp. 1-12.

[12] J. B. Berger, M. Hertzum, and T. Schreiber, "Does local government staff perceive digital communication with citizens as improved service?," Government Information Quarterly, vol. 33, iss. 2, 2016, pp. 258-269.

[13] J. D. Twizeyimana and A. Andersson, "The public value of EGovernment - A literature review," Government Information Quarterly, vol. 36, iss. 2, 2019, pp. 167-178.

[14] P. N. Sharma, F. V. Morgeson, S. Mithas, and S. Aljazzaf, "An empirical and comparative analysis of E-government performance measurement models: Model selection via explanation, prediction, and parsimony", Government Information Quarterly, vol. 35, iss. 4, 2018, pp. 515-535.

[15] E. Falco and R. Kleinhans, "Beyond technology: Identifying local government challenges for using digital platforms for citizen engagement," International Journal of Information Management, vol. 40, 2018, pp. 17-20. 